\title{
Talking the Walk: Perceptions of Neighborhood Characteristics from Users of Open Streets Programs in Latin America and the USA
}

\author{
Susan G. Zieff • Elaine A. Musselman • Olga L. Sarmiento • Silvia A. Gonzalez • \\ Nicolas Aguilar-Farias • Sandra J. Winter • J. Aaron Hipp • Karoll Quijano • \\ Abby C. King
}

Published online: 11 June 2018

(C) The New York Academy of Medicine 2018, corrected publication [June/2018]

\begin{abstract}
Physical inactivity is estimated to be the fourth leading cause of global mortality. Strategies to increase physical activity (PA) increasingly emphasize environmental and policy changes including the modification of neighborhood environments to promote walking and other forms of healthy activity. Open Streets (OS) initiatives, an important and growing strategy to modify neighborhood environments for PA, create temporary parks for recreational activity by closing
\end{abstract}

The original version of this article was revised: Coauthor Olga L. Sarmiento was listed with an affiliation-Children's Hospital of Eastern Ontario Research Institute - that does not apply to her (only "University de los Andes Bogota, Colombia" is a correct affiliation for her); and the version of Table 4 presented in the article was not the correct version of the table.

S. G. Zieff $(\bowtie) \cdot$ E. A. Musselman

San Francisco State University, San Francisco, CA, USA

e-mail: susangz@sfsu.edu

O. L. Sarmiento · S. A. Gonzalez · K. Quijano

Universidad de los Andes, Bogota, Colombia

S. A. Gonzalez

Children's Hospital of Eastern Ontario Research Institute, Ottawa, Ontario, Canada

N. Aguilar-Farias

Universidad de la Frontera, Temuco, Chile

S. J. Winter - A. C. King

Stanford University School of Medicine, Palo Alto, CA, USA

J. A. Hipp

North Carolina State University, Raleigh, NC, USA streets to motor vehicle traffic, thereby offering health and community building benefits. We used the Stanford Neighborhood Discovery Tool (DT) - photo/voice software on a tablet - to train neighborhood residents to act as "citizen scientist" observers of the local built environment on a non-event day and during an OS initiative. The purposes of this project were as follows: (1) to assess adult residents' perceptions of neighborhood characteristics of the OS initiative in three socioeconomically diverse sites and (2) to test the DT for use in three international urban settings with OS initiatives; Bogota, Colombia; San Francisco, USA; and Temuco, Chile, among a multigenerational, multiethnic sample of adults including, for the first time, a vulnerable population of homeless adults (Bogota). Using the DT, participants walked an OS route taking photos and recording reasons for the photos, then completed a 25-item demographic/ environmental observation survey and a 16-item Reflection Survey on perceived environmental changes. A total of 18 themes were reported by participants with areas of overlapping themes (e.g., Community and Social Connectedness) and areas where a single site reported a theme (e.g., Social Isolation in Older Adults). Ten of the 18 themes were identified by at least two sites including "Bike Resources" and "Services", indicating the value of programming at OS initiatives. The themes of "Festive Environment" and "Family Friendly Environment" reflect the quality of the overall environment for participants. Four themes (Community and Social Connectedness, Family Friendly Environment, PA, and Safety) were reported by all sites. Three of the four unifying themes were also ranked among the 
highest reported categories of "seemed better" on the Reflection Survey (Ease of Walking, Overall Safety of Neighborhood, and Friendliness of Environment), providing additional confirmation of the shared experience of social, health, and psychological benefits from OS initiatives. OS initiatives offer a global strategy for increasing neighborhood opportunities for PA and a potential site for training citizen scientists to document environmental influences on PA.

Keywords Open Streets · Physical activity - Discovery tool $\cdot$ Neighborhood $\cdot$ Citizen scientist $\cdot$ Built environment

\section{Introduction}

Globally, approximately $23 \%$ of adults are insufficiently active [1]. In 2008, physical inactivity accounted for more than 5.3 million deaths worldwide [2]. Strategies to promote physical activity (PA) increasingly emphasize environmental and policy changes [3-5]. One approach that has been gaining recognition is the modification of neighborhood environments to promote walking and other forms of PA that support healthier lifestyles [6]. Living in more walkable neighborhoods has been associated with lower body mass index among older adults [7], while living in close proximity to parks has been associated with increased PA among adults and children [8]. However, disadvantaged populations are more likely to live in neighborhoods with fewer environmental supports, and which have lower perceived safety, leading to reduced PA $[9,10]$.

Open Streets (OS) initiatives, a worldwide phenomenon begun in the 1960s, are an important and growing strategy to modify neighborhood environments for PA. OS initiatives, which create temporary parks for recreational activity by closing streets to motor vehicle traffic, currently occur in more than 400 locations worldwide [11-13]. Similar to the benefits from park usage [14], OS initiatives offer health [15] and community building benefits [16], including socially inclusive programs [13]. Participants typically report improved feelings of neighborhood safety during OS from increased numbers of people on the streets [15] and safety benefits have been used to support OS policies [13, 17]. OS are an important strategy for promoting PA due to their flexibility in structure and implementation process [18], highlighting their potential for establishing an "urban culture of health
[13]". A review of OS implementation shows variability of features such as route length and consistency, regularity and scheduling of events, programming offered, and organizational administration [11]. In addition, OS initiatives sometimes face barriers, such as lack of funding and overly complicated permitting processes. Marketing and advocacy efforts, especially from local residents, can be valuable in sustaining local initiatives [19]. To date, there has been no audit of perceived changes to neighborhood active living environments resulting from implementation of and participation in an OS initiative.

We used the Stanford Neighborhood Discovery Tool (DT) $[20,21]$ to train neighborhood residents to be "citizen scientist" observers of the local built environment influences on PA. The current project builds on previous studies [22-25] using a citizen scientist engagement approach and the DT to assess changes in perception of neighborhood barriers and facilitators to PA from implementation of OS initiatives. We chose to use the DT at OS because of the opportunity for pre-post evaluation and to test the feasibility of training local citizen-scientists as observers and reporters of OS activities.

\section{Purpose}

The purpose of this project was twofold: (1) to assess and compare adult residents' perceptions of neighborhood characteristics (e.g., safety, PA barriers) on a non-event vs. an event day of the OS initiative in three sites that differed in socioeconomic and inequality characteristics: Bogotá, Colombia; San Francisco, USA; and Temuco, Chile; and (2) to test the acceptability and utility of the DT for use with OS initiatives in three international urban settings which involved multigenerational, multiethnic samples of adults and which included, for the first time, a vulnerable population of homeless adults (Bogotá).

\section{Methods}

The Institutional Review Board at each participating university (Universidad de los Andes, Colombia; San Francisco State University, CA, USA; Stanford University, CA, USA; and Universidad de la Frontera, Chile) approved the protocol for research. A shared protocol was used at each site which allowed for local variations in participant recruitment strategies and population 


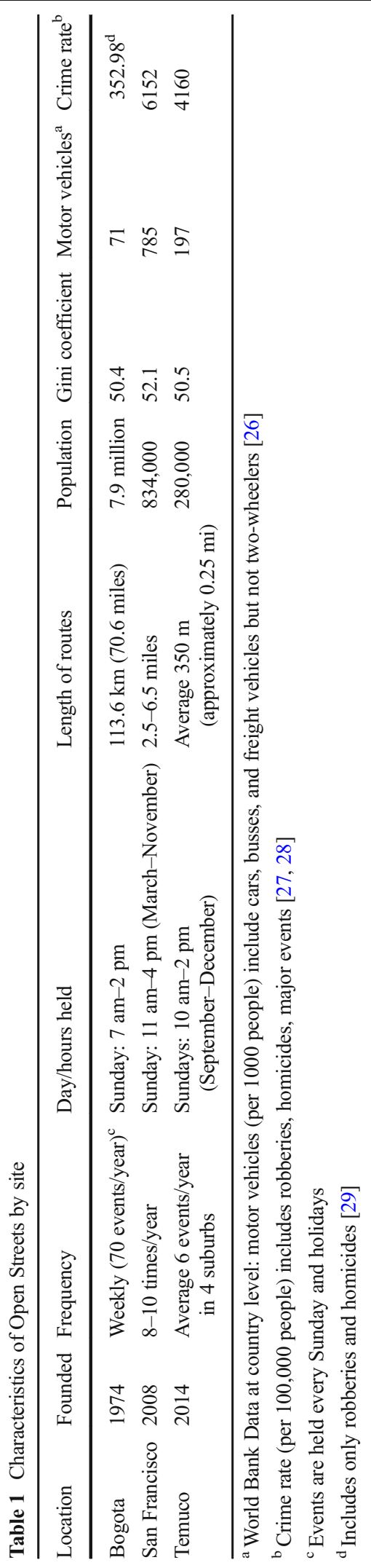

sampling. All participants signed informed consent forms approved by their local institutions.

\section{Study Sites}

Three sites were selected for inclusion because they met the following criteria: each had an ongoing OS initiative; the sites offered the opportunity to work with diverse populations; and each site researcher was an experienced OS evaluator. The three targeted cities differed in some sociodemographic characteristics (Table 1). As of 2015, Bogotá had 7.9 million inhabitants, San Francisco had 865,000 inhabitants, and Temuco had 280,000 inhabitants. The three cities show similar income inequality as reflected by the Gini coefficients (San Francisco 52.1, Temuco 50.5, Bogota 50.4) [26, 30, 31]. The Gini coefficient reflects the extent to which the distribution of income or consumption expenditure among individuals or households within an economy deviates from a perfectly equal distribution. A Gini index of 0 represents perfect equality, whereas an index of 100 represents perfect inequality [26]. The Gini coefficient reports on income disparity within a selected society but does not allow for comparison between geographical locations.

The OS initiative in Bogotá, Ciclovía, is a weekly, community-wide policy and planning intervention for promoting PA. The Ciclovía of Bogotá began in 1974 and is the largest OS in the world. The pedestrian/cycling route remains consistent throughout the year, covering $120 \mathrm{~km}$ of city streets, and connecting low, middle, and high-income neighborhoods [13] with free community exercise and dance classes offered in parks adjacent to the route (Fig. 1). The Ciclovía is funded through public and private organizations and is operated by the District Institute of Recreation and Sports [13]. Therefore, reported data includes the entire city. In terms of safety, the combined homicide and robbery rate of Bogotá for 2014 was 352.98 per 100,000 inhabitants [29]. Data collection was conducted from June 2015 to August 2016.

In San Francisco, Sunday Streets SF (the local OS program) uses a model of rotating routes across the city, traversing up to 24 different neighborhoods [11]. Sunday Streets was created in 2008, and programming for each route is planned in coordination with community groups. Funding for Sunday Streets comes from both public (San Francisco Departments of Public Health and the Municipal Transportation Agency) and private (e.g., healthcare corporations) sources [17]. The Bayview 
route, included in this study, fulfills initiative criteria: the neighborhood is under-served for recreational resources, reports higher than city average chronic disease rates, and serves predominantly low-income, ethnic minority resident populations (Fig. 1) [32], and traverses approximately 3.5 miles. Annual total reported crime in San Francisco is 6152/100,000 [27]. Data were collected between September 2014 and April 2015.

In Temuco, Calles Abiertas (the OS initiative) was established in 2014, and the program is implemented every Sunday from September to December in four neighborhoods differing in socioeconomic status (low- and middle-income). On average, six events per year are completed depending on weather and holiday schedule. OS in Temuco cover approximately two blocks (350 m) (Fig. 1) and receive government funding. Some activities included in the events are Zumba classes, soccer, volleyball, and motorskill circuits for children. Temuco has 4160 crimes per 100,000 inhabitants including robbery, homicides, and other major events [28]. Data collection was conducted between September 2015 and December 2015 in two OS locations.

Table 1 offers description of OS and city characteristics that influence outdoor PA considering the influence of known barriers: crime, vehicular traffic, and population $[7,9,10]$.

\section{Stanford Neighborhood Discovery Tool (DT)}

The DT is a computerized tablet/smartphone-based participatory tool, available in English and Spanish, that incorporates photo and voice technology, GPS route

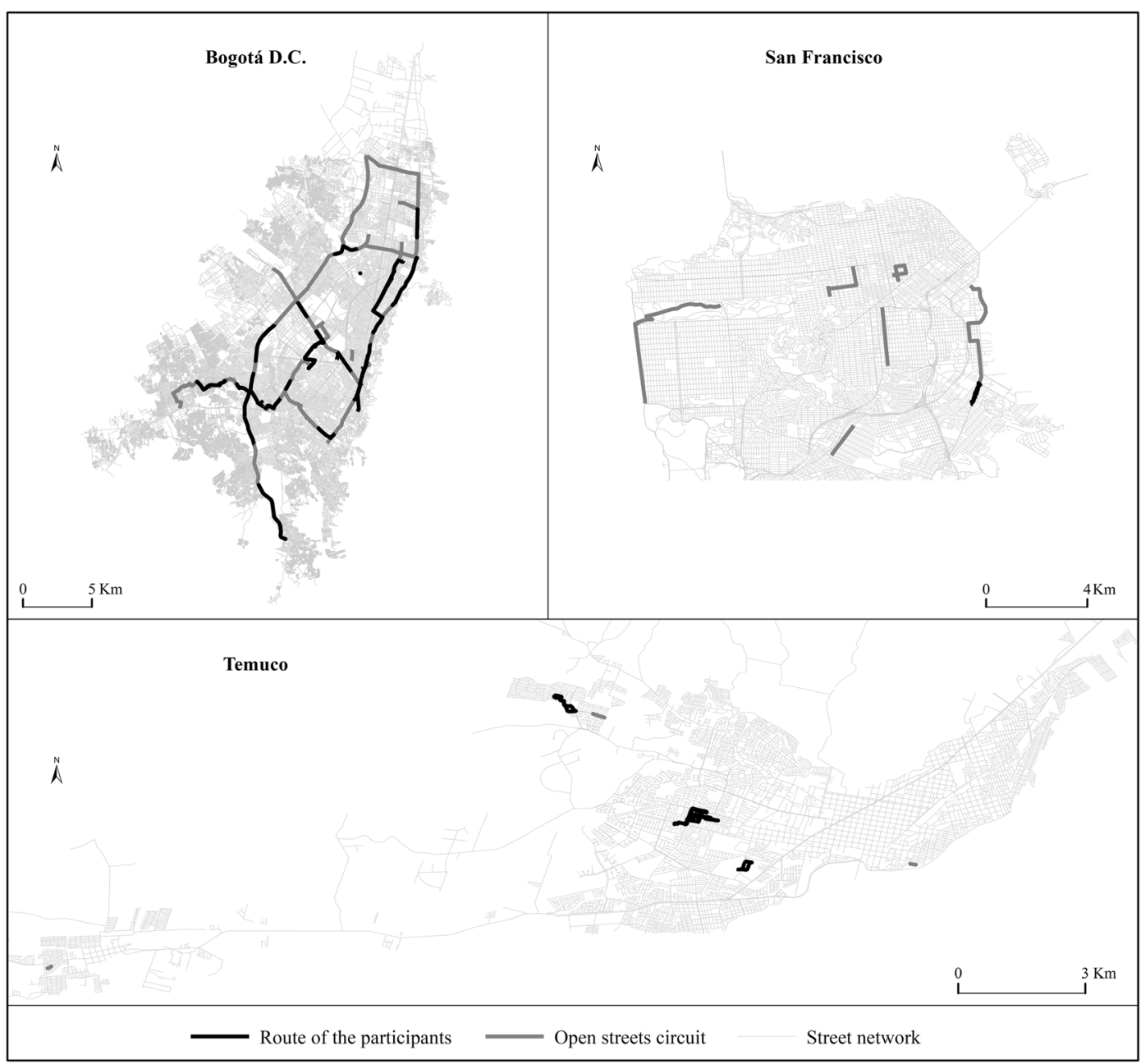

Fig. 1 Cycling routes of Bogotá, San Francisco, and Temuco 
tracking, and a short survey to assess the local environment. The DT has proven to be feasible for a range of individuals - from youth through older adults - to observe and describe barriers to and facilitators of active living [24]. It also has been shown to help identify microscale environmental elements that influence adults' choices related to being active [33]. Community residents serving as "citizen scientists" have used the data they gathered with the DT to advocate successfully for neighborhood improvements to support health and quality of life [34].

\section{Procedures}

Data were collected during the hours and days of the OS program occurring at each site. Upon arrival for the first data collection event (non-OS day), participants received information about the project and signed consent forms. The DT and surveys were designed to be easy to use regardless of education or experience with technology and the 5-10-min training involved hearing a brief description of the purpose and operation of the DT and its application to this project. Participants learned to take photos, audio-record a narrative about why they took the photo, and complete the 25-item DT survey.

At the end of each data collection event, participants reviewed and approved the photos and audio narratives they recorded. After the second data collection event (OS day), all participants additionally completed a 16item Reflection Survey (designed by 1st author; Spanish translation by 4 th author) that asked them to evaluate their pre-post perceptions of 16 built environment neighborhood features across the two data collection points, which they ranked on a 5-point Likert type scale, with 1 indicating "seemed better," 3 indicating "no change," and 5 indicating "seemed worse." All participants walked with a field work coordinator or trained research assistant.

\section{Design and Recruitment}

We used a pre-post method that assesses and compares adult residents' perceptions of built environment influences on PA during a non-OS day (pre-test) and an OS day (post-test). Each participant walked the same route or section of a route twice (pre-post), for approximately
30 min each time (Table 1). A total of 50 participants (Bogotá, $N=32$; San Francisco, $N=10$; Temuco, $N=8$ ) adults completed two walks using the DT. The participants in Bogotá and Temuco used the Spanish language versions of the DT and the Reflection Survey.

In Bogotá, 32 adults were selected from low-, middle-, and high-income neighborhoods around the circuit of the Ciclovía, including 5 adults without homes who reported that the Ciclovía was a program they used for recreation. Modest incentives were offered for citizen science participation, including sports water bottles, food, and yoga mats. In San Francisco, participants were ten adults who lived within one city block of any section of the Bayview neighborhood Sunday Streets route. The Bayview Branch of the YMCA of San Francisco assisted recruitment by advertising the project through posted flyers and emails to members, and offered lunch, a t-shirt, and water bottle to each participant. In Temuco, recruitment of eight older adults was conducted door to door in two different neighborhoods, with OS and researchers engaged with prospective participants as they walked through the area. No incentives were provided.

\section{Data Analysis}

\section{Survey Data}

Quantitative DT survey data were downloaded from the tablet for analysis. Descriptive statistics were calculated for demographic characteristics (e.g., age, gender, ethnicity, race, education level) and environmental features (e.g., sidewalk cracks, gangs, homeless, garbage, graffiti). All analyses were conducted using SAS 9.3, Excel, or SPSS 22.0.

\section{Discovery Tool Photo/Voice Themes}

Content analysis of the qualitative audio narratives and photos was conducted using a hybrid approach. Data were downloaded from the DT and analyzed by a minimum of two researchers or research assistants. Each site was asked to identify the top 10 themes by frequency of mention that emerged from their review of the photos and narratives with corroborating sample quotes and photos. The 10 themes from each site were then merged to create a complete list of themes that included those with contextual relevance for a single site. In Bogotá and San Francisco, researchers and research assistants 
jointly coded the data with the PI. Two researchers in Temuco coded the qualitative data using atlas.ti software from which they developed themes.

\section{Results}

\section{Walk Characteristics}

Participants were asked to walk for approximately $30 \mathrm{~min}$ at each site and the number of photos taken ranged from 8.75 (SD 1.67) in Temuco to 10.2 (SD 4.3) in Bogota during the non-OS day and 8.5 (SD 0.76) in Temuco to 9.9 (SD 3.8) in Bogota on OS event day. On the non-OS day, participants recorded from 8.75 (SD 1.49) narratives in Temuco to 10.1 (SD 5.04) narratives in San Francisco. On OS event day, participants recorded from 8.25 (SD 0.71) narratives in Temuco to 11.3 (SD 4.11) narratives in San Francisco.

\section{Participants}

Women accounted for the majority of participants in San Francisco (70\%) and Temuco (75\%), but fewer than half of participants $(37.5 \%)$ in Bogotá. Participant ages ranged from 18 to 64 years in Bogotá, 18-89 years in
SF, and from 65 to 89 years in Temuco. Almost half of participants $(44.8 \%)$ in Bogotá and the majority of participants in SF $(80 \%)$ reported attending or completing college. In contrast, participants in Temuco reported mainly high school education $(63 \%)$. Living situation differed by site, with route participants living exclusively in single-family homes in Temuco and a mix of single-family, multiple-family dwellings or apartments in San Francisco (Table 2).

\section{Perceived Changes to Neighborhood Environment}

DT tablet survey data were collected on neighborhood infrastructure impacting PA (e.g., cracks in sidewalks, sidewalk corner ramps, graffiti, and traffic calming facilities) by participants on OS days. Results showed no statistically significant differences between sites.

As reported in the Reflection Survey completed by participants after the second walk, "Friendliness of environment" and "Number of cars" were the components with the highest percentage of participants reporting "seemed better" across sites (Table 3). Improvement in overall neighborhood safety was reported in Bogotá (74.2\%) and SF (70\%), while only $25 \%$ of the older participants being targeted in Temuco perceived an improvement. More than half of participants (62.5\%)

Table 2 Sociodemographics by site (\%)

\begin{tabular}{|c|c|c|c|c|}
\hline & & Bogota, $N=32$ & $\mathrm{SF}, N=10$ & Temuco, $N=8$ \\
\hline Age & $\begin{array}{l}17 \text { years or younger } \\
18-35 \text { years } \\
36-49 \text { years } \\
50-64 \text { years } \\
65-89 \text { years } \\
90+\text { years }\end{array}$ & $\begin{array}{l}0 \\
48.3 \\
27.6 \\
24.1 \\
0 \\
0\end{array}$ & $\begin{array}{l}0 \\
50.0 \\
10.0 \\
30.0 \\
10.0 \\
0\end{array}$ & $\begin{array}{l}0 \\
0 \\
0 \\
0 \\
100\end{array}$ \\
\hline Gender & $\begin{array}{l}\text { Female } \\
\text { Male }\end{array}$ & $\begin{array}{l}37.5 \\
62.5\end{array}$ & $\begin{array}{l}70.0 \\
30.0\end{array}$ & $\begin{array}{l}75.0 \\
25.0\end{array}$ \\
\hline Ethnicity & $\begin{array}{l}\text { Hispanic or Latino } \\
\text { Not Hispanic or Latino }\end{array}$ & $\begin{array}{l}100 \\
0\end{array}$ & $\begin{array}{l}20.0 \\
80.0\end{array}$ & $\begin{array}{l}100 \\
0\end{array}$ \\
\hline 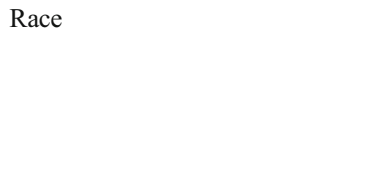 & $\begin{array}{l}\text { American Indian/Alaskan Native } \\
\text { Asian } \\
\text { Black or African Am } \\
\text { Native Hawaiian/PI } \\
\text { White } \\
\text { Other }\end{array}$ & Not asked & $\begin{array}{l}0 \\
20.0 \\
50.0 \\
0 \\
10.0 \\
0\end{array}$ & Not asked \\
\hline Highest education level completed & $\begin{array}{l}\text { Less than } 7 \text { th grade } \\
\text { Junior high/middle school } \\
\text { Some high school } \\
\text { Completed high school } \\
\text { Some college/vocational } \\
\text { Completed college/university }\end{array}$ & $\begin{array}{l}24.1 \\
13.8 \\
6.9 \\
10.3 \\
17.2 \\
27.6\end{array}$ & $\begin{array}{l}0 \\
0 \\
0 \\
20.0 \\
50.0 \\
30.0\end{array}$ & $\begin{array}{l}25.0 \\
0 \\
12.5 \\
62.5 \\
0 \\
0\end{array}$ \\
\hline Residence & $\begin{array}{l}\text { Single family } \\
\text { Multiple family } \\
\text { Apartment/condo/townhouse }\end{array}$ & Not asked & $\begin{array}{l}60.0 \\
10.0 \\
30.0\end{array}$ & $\begin{array}{l}100 \\
0 \\
0\end{array}$ \\
\hline
\end{tabular}


Table 3 Reflection Survey: perceived environmental changes (\% ranked as "seemed better")

\begin{tabular}{|c|c|c|c|c|c|c|}
\hline \multirow[t]{2}{*}{ Environmental characteristics ${ }^{\mathrm{a}}$} & \multicolumn{2}{|c|}{ Bogota $(n=32)$} & \multicolumn{2}{|c|}{ San Francisco $(n=10)$} & \multicolumn{2}{|c|}{ Temuco $(n=8)$} \\
\hline & $\%$ & Mean (SD) & $\%$ & Mean (SD) & $\%$ & Mean (SD) \\
\hline Quality of sidewalks & 22.6 & $3.13(0.72)$ & 10.0 & $2.9(0.74)$ & 62.5 & $3.75(0.71)$ \\
\hline Ease of walking & 83.9 & $4.16(1.07)$ & 30.0 & $3.10(0.88)$ & 87.5 & $4.00(0.53)$ \\
\hline Width of streets & 61.3 & $3.90(1.22)$ & 10.0 & $3.00(0.47)$ & 0 & $3.00(0)$ \\
\hline Overall safety of neighborhood & 74.2 & $4.16(0.97)$ & 70.0 & $3.90(0.99)$ & 25.0 & $3.25(0.46)$ \\
\hline Number of cars & 74.2 & $4.00(1.21)$ & 80.0 & $4.10(0.74)$ & 87.5 & $4.50(0.76)$ \\
\hline Amount of trees, plants, other landscape & 32.3 & $3.45(0.72)$ & 20.0 & $3.30(0.68)$ & 25.0 & $3.25(0.46)$ \\
\hline Number of places to see or walk to & 51.6 & $3.74(0.82)$ & 80.0 & $4.10(0.73)$ & 87.5 & $4.25(0.71)$ \\
\hline Number of street crossing lights/signs & 35.5 & $3.42(0.85)$ & 50.0 & $3.60(0.70)$ & 0 & $3.00(0)$ \\
\hline Amount of graffiti, trash, street debris & 29.0 & $3.06(1.03)$ & 30.0 & $3.30(0.82)$ & 0 & $3.00(0)$ \\
\hline Places closer to walk to & 54.8 & $3.77(0.96)$ & 40.0 & $3.40(0.51)$ & 0 & $3.38(0.52)$ \\
\hline Places farther to walk to & Not asked & - & 30.0 & $3.30(0.48)$ & 0 & $3.00(0)$ \\
\hline Quality of trees, plants, other landscape & 48.4 & $3.68(0.79)$ & 30.0 & $3.30(0.48)$ & 62.5 & $3.75(0.71)$ \\
\hline Friendliness of environment & 96.8 & $4.52(0.57)$ & 80.0 & $4.30(0.82)$ & 75.0 & $4.38(0.92)$ \\
\hline Overall impact on likelihood of walking & Not asked & - & 70.0 & $4.11(0.78)$ & 75.0 & $4.13(0.83)$ \\
\hline Availability of benches, places to rest & 38.7 & $3.32(1.01)$ & 40.0 & $3.22(1.3)$ & 25.0 & $3.13(0.64)$ \\
\hline
\end{tabular}

${ }^{\text {a } I t e m s ~ r a n k e d ~ 1-2, ~ s e e m e d ~ w o r s e ; ~} 3$, no change; 4-5, seemed better

in Temuco reported perceptions of an improvement in sidewalks, though no change was reported by the majority of participants in Bogotá $(67.7 \%)$ and SF (80\%).

\section{DT Photo/Voice Themes for Context-Specific Evaluation of OS}

All sites reported the top 10 environmental themes related to the OS, compiled from the coded qualitative photo and audio data, in rank order according to frequency of mention among participants. A total of 18 themes were found (Table 4). The results show that there were some similar themes reported across sites (e.g., community and social connectedness) as well as distinct themes reported at individual sites (e.g., social isolation among the older adults in Temuco). Ten of the 18 themes were identified by at least two sites. The shared themes included components such as "bike resources," "services," "festive environment," and "family friendly environment." Four themes (community and social connectedness, family friendly environment, physical activities, and safety) were reported by all sites. Using the "ease of walking" construct from the Reflection Survey as a proxy for PA, three of the four themes common to all sites were also ranked among the highest reported categories of "seemed better" on the Reflection Survey
(Ease of Walking, Overall Safety of Neighborhood, and Friendliness of Environment). In addition, the older adult population in Temuco indicated a lack of ageappropriate OS activities. Furthermore, the individuals without homes in Bogota underscored the importance of having an inclusive program in which cars are replaced by people in main streets and highlighted the health benefits of the program.

\section{Discussion}

This study assessed the perceived environmental attributes influencing PA before and during OS initiatives in three cities similar in income inequality located in three countries differing in sociodemographic characteristics using a mixed-methods design. Although more basic forms of photo/voice technology have been used in observational studies of the built environment in relation to PA, no study has yet implemented photo/voice technology with diverse populations participating in OS initiatives. The current study adds to the existing literature by exploring the use of local residents to systematically capture local contexts of OS Initiatives - an increasingly popular municipal PA and community engagement activity around the world [13]. 
Table 4 Top 10 photo/narrative themes during Open Streets (\# indicates ranking)

\begin{tabular}{|c|c|c|c|}
\hline Theme & Bogota & San Francisco & Temuco \\
\hline Bike Resources & $\begin{array}{l}\text { "I suggest an educational campaign that } \\
\text { makes people more aware of the proper } \\
\text { use of the bike. I suggest some kind of } \\
\text { campaign that teaches how to ride a bike, } \\
\text { to look around before crossing a street, to } \\
\text { be aware that there are other cyclists, so } \\
\text { accidents will be avoided. Some kind of } \\
\text { culture, right?" }\end{array}$ & $\begin{array}{l}\text { "Having a place to rent } \\
\text { (bikes/equipment) is a } \\
\text { great incentive for } \\
\text { exercise. Having a place to } \\
\text { learn to ride is a great } \\
\text { incentive for exercise." }\end{array}$ & \\
\hline $\begin{array}{l}\text { Community } \\
\text { and Social } \\
\text { Connectedness }\end{array}$ & $\begin{array}{l}\text { "Something } \\
\text { positive in the } \\
\text { Ciclovía is that, } \\
\text { besides promoting } \\
\text { physical activity, it } \\
\text { is important }\end{array}$ & $\begin{array}{l}\text { Live music encourages people to come } \\
\text { out" }\end{array}$ & $\begin{array}{l}\text { "I enjoy open streets as my grandson comes } \\
\text { every Sunday to participate and play. After } \\
\text { that, we have lunch together... It is a nice } \\
\text { routine" }\end{array}$ \\
\hline $\begin{array}{l}\text { Environmental } \\
\text { Quality }\end{array}$ & $\begin{array}{l}\text { "Well, comparing with a weekday, there } \\
\text { is less pollution, less noise, less dangers } \\
\text { for the people" }\end{array}$ & $\begin{array}{l}10 \\
\text { "Paint peeling makes you feel unwanted, } \\
\text { time not taken to make it pretty. Yet, the } \\
\text { beautiful murals get changed regularly" }\end{array}$ & $\begin{array}{l}\text { "I like music, but some neighbours } \\
\text { complain about the music level. There is a } \\
\text { church very close and has a mass/service } \\
\text { every Sunday during OS" }\end{array}$ \\
\hline $\begin{array}{l}\text { Family } \\
\text { Friendly } \\
\text { Environment }\end{array}$ & $\begin{array}{l}\text { "There is a much } \\
\text { bigger space to walk, } \\
\text { and there are many } \\
\text { people, this makes a } \\
\text { little bit nicer to go } \\
\text { out to walk or do } \\
\text { physical activity" }\end{array}$ & $\begin{array}{l}\text { "I see happiness and I see potential for it } \\
\text { (the neighborhood) to be the best place to } \\
\text { raise a family" }\end{array}$ & $\begin{array}{l}{ }^{7} \\
\text { "It is fun to watch children playing in those } \\
\text { games (balance and motor skills circuit), } \\
\text { my grandchildren love them" }\end{array}$ \\
\hline $\begin{array}{l}\text { Festive } \\
\text { Atmosphere }\end{array}$ & & $\begin{array}{l}\text { "Live music encourages people to come } \\
\text { out" }\end{array}$ & \\
\hline
\end{tabular}

The use of repeated observations which captured differences in perceptions occurring before and during OS at all sites shows that the DT was a useful tool for training local citizen scientists to notice changes to the built environment that support or interfere with PA. The reported differences in results across sites suggests that the DT is sensitive enough to allow respondents to report context-specific built environmental infrastructure as well as elements of OS initiatives that support PA or that need improvement. However, the results show surprising similarities in issues related to the experience of OS initiatives across sites as demonstrated through the observational feedback. Despite differences in site characteristics such as crime rate, motor vehicle ownership and population, the response to OS suggests that the similar level of income inequality among sitesa variable influencing the design of local routes - possibly contributes to comparable experiences among OS participants.
There were also some unique themes arising due to geographical and cultural context, differences in population characteristics, and specific OS programming. Overall, using street-based infrastructure for community-based PA and recreational programs offers benefits and challenges regardless of site location. Furthermore, the inclusion of vulnerable populations in these community programs in cities experiencing income inequality makes OS programs a unique and promising example for addressing disparities in access to recreational opportunities.

The substantial increase in number of individuals in the area during OS may influence the perception of an improvement in some of the environmental features. While the increase in number of youth, decreased number of cars, and increased friendliness and safety of the neighborhood are expected benefits of OS, the reported increase in sighting of graffiti in SF during OS, for 
Table 4 (continued)

\begin{tabular}{|c|c|c|c|}
\hline $\begin{array}{l}\text { Healthy Food } \\
\text { Availability }\end{array}$ & & $\begin{array}{l}\text { "Unhealthy fried chicken is discouraging } \\
\text { (to see) after doing physical activity" }\end{array}$ & \\
\hline $\begin{array}{l}\text { Lack of } \\
\text { Suitable } \\
\text { Activities for } \\
\text { Older Adults }\end{array}$ & & & $\begin{array}{l}\text { "I like open } \\
\text { streets. It looks } \\
\text { very funn, but } \\
\text { I just watch" }\end{array}$ \\
\hline $\begin{array}{l}\text { Open Streets } \\
\text { was Too Short }\end{array}$ & & & $\begin{array}{l}6 \\
\text { "OS is about two blocks which is too short, } \\
\text { but has lot of activities for children" }\end{array}$ \\
\hline $\begin{array}{l}\text { Physical } \\
\text { Activity at } \\
\text { Sunday Streets }\end{array}$ & $\begin{array}{l}\text { "I think that the Ciclovía is a great place, } \\
\text { which provides the opportunity to } \\
\text { exercise for many people, for people that } \\
\text { may not have the access or tools for } \\
\text { physical activity. It provides services like } \\
\text { bike rentals, dancing classes, and I think } \\
\text { that it is very important for the } \\
\text { community, because it is for everyone, it } \\
\text { is free, and it is available every Sunday } \\
\text { for anyone who wants to attend. This is } \\
\text { very important for the community to be } \\
\text { physically active, at least on Sundays." }\end{array}$ & $\begin{array}{l}\text { "Having streets blocked } \\
\text { off so you can exercise is } \\
\text { great. Open space is great } \\
\text { for exercise." }\end{array}$ & $\begin{array}{l}\text { "I like to watch people dancing, Zumba is } \\
\text { very popular among women ....it is a nice } \\
\text { break after a having a hard week" }\end{array}$ \\
\hline $\begin{array}{l}\text { Revitalization } \\
\text { of Public Space }\end{array}$ & & & $\begin{array}{l}\text { comple come } \\
\text { from other } \\
\text { areas of the } \\
\text { city... }\end{array}$ \\
\hline Route & $\begin{array}{l}\text { "In this point, we have a connection } \\
\text { between the Ciclovía and the cycle lanes. } \\
\text { The cycle lane of the Villavicencio Avenue } \\
\text { is directly connected to the Ciclovía of } \\
\text { Sundays and holidays, and this is } \\
\text { something positive of the Ciclovía, to } \\
\text { have the opportunity to connect with the }\end{array}$ & & $\begin{array}{l}\text { "I like that this Open Street is close to my } \\
\text { house, but it should be connected to other } \\
\text { more important places of the city such as } \\
\text { the stadium. It should be longer to include } \\
\text { more people" }\end{array}$ \\
\hline
\end{tabular}

example, was unexpected, and may be due to the process of participants learning how to observe the environment rather than an actual change. Such observations deserve further evaluation.

\section{Fulfillment of the Goals of OS}

The study results add to our understanding of the intersections between residents' perceptions of OS initiatives and the influence of neighborhood built environments on PA. The DT data suggest that the PA opportunities provided through OS initiatives are perceived and highlighted as generally beneficial by participants across sites. Three overarching themes, discussed below, that emerged from the theme analysis and previous literature on OS, offer confirming insights into the health and community benefits of OS initiatives regardless of locale.
Provide Physical Activity to Under-Resourced Communities

Three of the themes (Bike Resources, Physical Activity, and Route) reference the ways that PA is a central component of OS initiatives for participants across sites. Bicycle programming, the availability of space for physical recreation, and free exercise classes have been demonstrated to support and encourage PA across populations [16, 21, 35]. Previous research [36] shows that providing programming during OS initiatives increases $\mathrm{PA}$ at the population level. Therefore, OS initiatives represent an opportunity to provide access to the benefits of leisure-time PA in municipalities with highly unequal resource distribution. However, OS initiatives are often community-based with limited funding and resources to support programming and activities. In the three sites investigated here, variables associated with 
Table 4 (continued)

\begin{tabular}{|c|c|c|c|}
\hline & $\begin{array}{l}\text { permanent cycle lanes." } \\
\text { "Well, we also see that the space used for } \\
\text { the Ciclovía is very narrow, and there are } \\
\text { a lot of people. We would like to have a } \\
\text { wider space, that they (the Ciclovía } \\
\text { coordinators) could give us a little bit } \\
\text { more of space of the avenue." }\end{array}$ & & \\
\hline Safety & $\begin{array}{l}\text { Well, we are arriving } \\
\text { to 'Socorro' } \\
\text { neighborhood, } \\
\text { where sometimes } \\
\text { there might be safety } \\
\text { problems, but the } \\
\text { implementation of } \\
\text { the Ciclovía changes }\end{array}$ & mic 1 & $\begin{array}{l}\text { "Lot of people cross } \\
\text { the street in this } \\
\text { corner, despite } \\
\text { there is no } \\
\text { pedestrian path. } \\
\text { We have to walk } 1\end{array}$ \\
\hline Services & $\begin{array}{l}\text { "Places like this one, } \\
\text { where there are } \\
\text { people selling juice, } \\
\text { water or something } \\
\text { to drink, simply } \\
\text { motivate me, } \\
\text { because I am the } \\
\text { kind of people who } \\
\text { go out to exercise and don't want to carry } \\
\text { anything while exercising. Then, stopping } \\
\text { to take a breath in a nice place, with a } \\
\text { beautiful view, motivates people to rest } \\
\text { and buy something. This is something } \\
\text { good for them (the vendors) and us." }\end{array}$ & $\begin{array}{l}\text { "I enjoy seeing the bikes out (in the racks) } \\
\text { because people are being physically } \\
\text { active" }\end{array}$ & \\
\hline
\end{tabular}

the structure and design of the OS were among the shared themes reported by participants that needed improvement (e.g., OS Too Short and Route). Increasing local government support to OS initiatives, either by increasing the number of events or through programming, would offer multiple health, community and social benefits to communities. In Bogotá, only $40 \%$ of the citizens are satisfied with parks and public spaces. Therefore, the Ciclovia functions as a temporary linear park to promote safe leisure activities mainly for low- to middle-income individuals. In San Francisco, there is open space near the Bayview neighborhood, but it is perceived to be too dangerous. The San Francisco OS provides a known strategy for increasing PA through the addition of open space, as well as the means to engage in PA through the provision of free bicycles and riding lessons. In Temuco, there was an effort in implementing OS in four areas of diverse socioeconomic levels at different times and days which is positive, but the extension and promotion of the events were limited. Older adults in Temuco recognized OS as an opportunity for being more active, but they were passive actors as activities were not appropriate for their functional capacities.

\section{Create and Transform Communities}

Three themes identified in the current research mention community connection (Community and Social Connectedness, Family Friendly Environment, and Festive Atmosphere), suggesting that social engagement among participants is important across sites. OS initiatives, regardless of geographical location, have the potential to increase social connection and reduce isolation. Previous research on OS in San Francisco and Bogota, reported the benefit of social interaction among participants [15] and social capital [37], respectively. In our study, participants from Bogota recognized OS as a place which promotes unity and shared values among citizens and quality time among family and friends. In the Bayview, the neighborhood is transformed as residents observe their neighbors engaging in outdoor activity, enjoying live music, and are motivated to go outside and join them. Older adults in Temuco reported positive feelings as OS offered a space for sharing with other generations, including family members. 
Table 4 (continued)

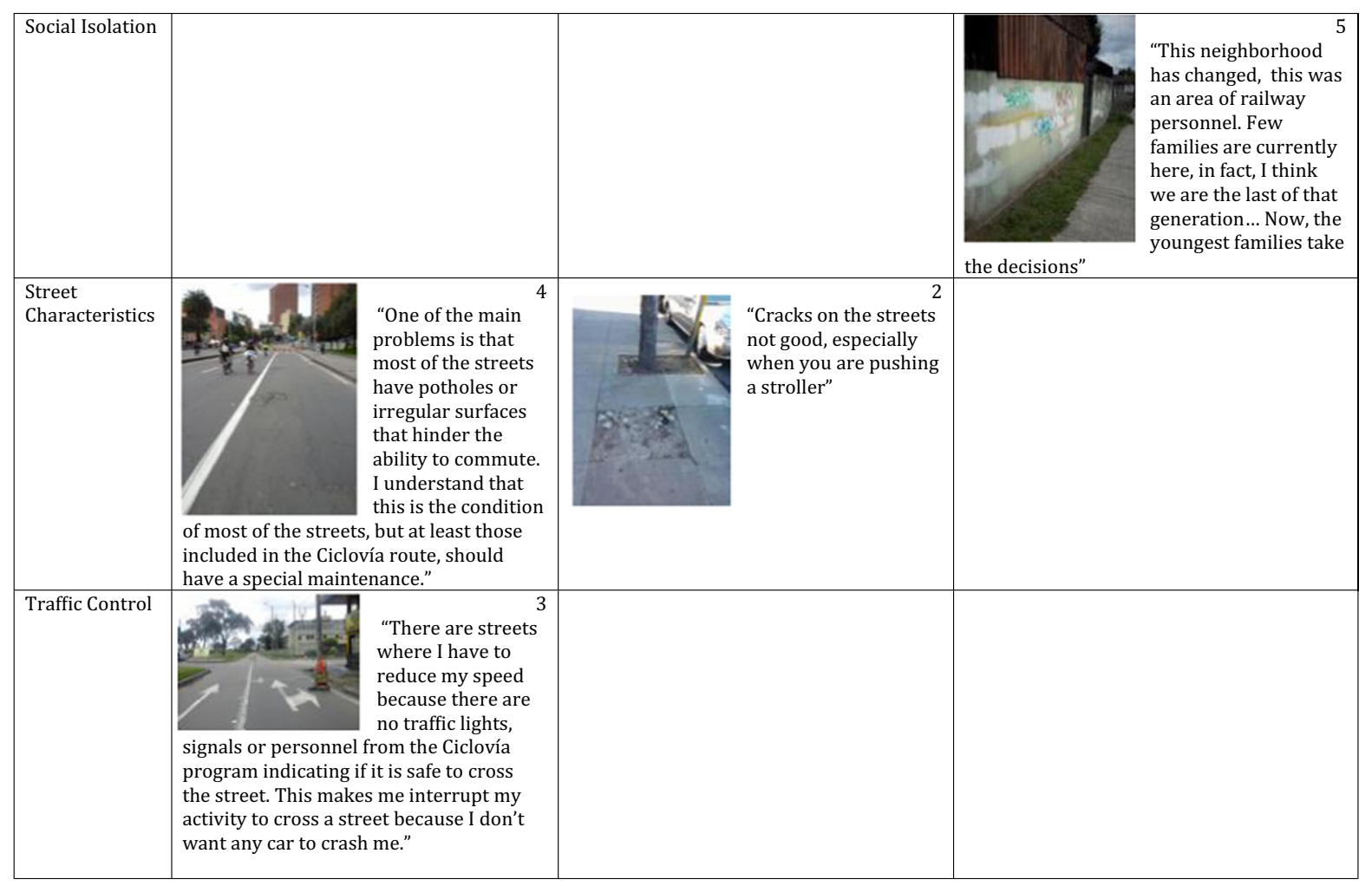

\section{Reduce Environmental Barriers to PA to Support Health}

Scholars have consistently reported that perceptions of safety are a significant barrier to participation in PA across age groups [38-42]. Among adult ethnic minority populations, Kwarteng et al. [42] recommended improving perceived safety along a walking route in conjunction with a walking intervention to improve PA outcomes. Among all three sites reported here, "Safety" was ranked first or second, suggesting that participants notice changes to their feelings of safety within the context of OS when more people are on the street and support arrangements (e.g., crossing guards) are available. Participants in Bogota and San Francisco reported improvements in perceptions of overall neighborhood safety, a documented benefit of OS programs that suggests a potential benefit for cities considering implementation of an OS initiative [37]. In Temuco, implementation of OS in recently renovated neighborhoods and parks may explain the small number of participants who perceived an improvement in safety. On the contrary, in Bogota, most of the participants perceived an increased safety, due to the flow of people in the streets, the presence of police and OS staff. In the San Francisco Bayview neighborhood, where residents report fear of crime as a barrier to outdoor activity, the activation of the streets during OS increases overall feelings of safety.

\section{Limitations}

Limited sample size from each site makes generalizing to the broader population in each locale difficult. It is also possible that the translation of the Reflection Survey to Spanish may have resulted in changes to the meaning for participants, although steps were taken to ensure that the translation was as close to possible to the English version of the Survey. Two walks were used for analysis in this investigation, with the OS walk defined as the post-test. This meant that we did not collect a true post-test walk to reflect perceived changes after the event. Finally, the community advocacy training portion of the Our Voice citizen science engagement model, which uses the Discovery Tool as a starting point for resident engagement [23]. was beyond the scope of this feasibility study. 
Table 4 (continued)

\begin{tabular}{l} 
Theme Bogota \\
\hline Traffic \\
Control \\
The participant refers that there \\
are some streets in the Ciclovía, \\
where she has to reduce the \\
speed of her activity because \\
there are no traffic lights, signals \\
or personnel from the Ciclovía \\
program indicating if it is safe to \\
cross the street.
\end{tabular}

\section{Conclusions}

This study shows that the Discovery Tool can be used effectively by diverse groups of adults living in socially and culturally diverse communities to record perceptions of neighborhood environmental features that impact PA behaviors occurring as part of OS activities. OS initiatives offer potential population-wide benefits for providing PA opportunities and community connections across sites, while additionally offering context-specific challenges that must be addressed at the local level.

Acknowledgements Partial funding was provided by the YMCA San Francisco Buchanan Branch (Zieff). Partial funding in support of the Discovery Tool came from The Robert Wood Johnson Grant ID\#73343 (PI: King). Bogotá's project was funded by the Research Office at Universidad de los Andes, and the Administrative Department of Science, Technology and Innovation (Colciencias grant number7262016). Aguilar-Farias and Hipp were funded by the Harvey A. Friedman Center for Aging at Washington University in St. Louis (DIUFRO DIE15-0004). Winter is supported by the Nutrilite Health Institute Wellness Fund provided by Amway to the Stanford Prevention Research Center. King is supported in part by US Public Health Service Grants 1R01DK102016 (PI: King), 1R01CA211048-01 (PI: King), 1U54EB020405 supporting the National Center for Mobility Data Integration and Insight (PI: S. Delp), and the Nutrilite Health Institute Wellness Fund provided by Amway to the Stanford Prevention Research Center.

\section{References}

1. Sallis JF, Bull F, Guthold R, Heath GW, Inoue S, Kelly P, et al. Progress in physical activity over the Olympic quadrenium. Lancet Physical Activity Series 2 Executive Committee. Lancet. 2016;388:1325-36.

2. Lee I-M, Shiroma EJ, Lobelo F, Puska P, Blair SN, Katzmarzyk PT. Effect of physical inactivity on major noncommunicable diseases worldwide: an analysis of burden of disease and life expectancy. Lancet. 2012;380(9838):219-29.

3. Feng J, Glass TA, Curriero FC, Stewart WF, Schwartz BS. The built environment and obesity: a systematic review of the epi-demiologic evidence. Health Place. 2010;16(2): 175-90.

4. Kerr J, Sallis JF, Owen N, de Bourdeaudhuij I, Cerin E, Sugiyama T, et al. Advancing science and policy through a coordinated international study of physical activity and built environments: IPEN adult methods. J Phys Act Health. 2013;10(4):581-601.

5. World Health Organization. Global strategy on diet, physical activity and health. 2017. www.who. int/dietphysicalactivity/goals/en/. Accessed July 8, 2017.

6. Brownson RC, Hoehner CM, Day K, Forsyth A, Sallis JF. Measuring the built environment for physical activity: state of the science. Am J Prev Med. 2009;36(4):S99-123.

7. King AC, Sallis JF, Frank LD, Saelens BE, Cain K, Conway $\mathrm{TL}$, et al. Aging in neighborhoods differing in walkability and income: associations with physical activity and obesity in older adults. Soc Sci Med. 2011;73(10):1525-33.

8. Sallis JF, Spoon C, Cavill N, Engelberg JK, Gebel K, Parker $\mathrm{M}$, et al. Co-benefits of designing communities for active living: an exploration of literature. Int J Behav Nutr Phys Act. 2015;12:30. 
9. Cutts BB, Darby KJ, Boone CG, Brewis A. City structure, obesity, and environmental justice: an integrated analysis of physical and social barriers to walkable streets and park access. Soc Sci Med. 2009;69(9):1314-22.

10. Foster S, Hooper P, Knuiman M, Christian H, Bull F, GilesCorti B. Safe RESIDential environments? A longitudinal analysis of the influence of crime-related safety on walking. Int J Behav Nutr Phys Act. 2016;13:22.

11. Open Street Project. Alliance for Biking \& Walking. 2012. http://openstreetsproject.org/open-streets-models/. Accessed July 9, 2017.

12. Wilson J, Tierney P, Kim M-S, Zieff SG. Temporary parks? Sunday streets, serving the need for urban outdoor recreation. J Park Recreat Adm. 2012;30(1):38-52.

13. Sarmiento OL, Díaz Del Castillo A, Triana CA, Acevedo MJ, Gonzalez SA, Pratt M. Reclaiming the streets for people: insights from Ciclovías Recreativas in Latin America. Prev Med. 2017;103S:S34-40.

14. Engelberg JK, Carlson JA, Black ML, Ryan S, Sallis JF. Ciclovía participation and impacts in San Diego, CA: the first CicloSDias. Prev Med. 2014;69(Suppl 1):S66-73.

15. Zieff SG, Kim MS, Wilson J, Tierney P. A "Ciclovia" in San Francisco: characteristics and physical activity behavior of Sunday Streets participants. J Phys Act Health. 2014;11(2): 249-55.

16. Torres A, Sarmiento OL, Stauber C, Zarama R. The Ciclovia and Cicloruta programs: promising interventions to promote physical activity and social capital in Bogotá, Colombia. Am J Public Health. 2013;103(2):e23-30.

17. Zieff SG, Hipp A, Eyler A, Kim MS. Ciclovia initiatives: engaging communities, partners and policymakers along the route to success. J Public Health Manag Pract. 2013;19(Suppl 1):S74-82.

18. Cohen D, Han B, Derose KP, Williamson S, Paley A, Batteate C. CicLAvia: evaluation of participation, physical activity and cost of an open streets event in Los Angeles. Prev Med. 2016;90:26-33. https://doi.org/10.1016/j. ypmed.2016.06.009.

19. Hipp JA, Bird A, van Bakergem M, Yarnall E. Moving targets: promoting physical activity in public spaces via open streets in the US. Prev Med. 2016;103:S15-20. https://doi. org/10.1016/j.ypmed.2016.10.014.

20. Buman MP, Winter SJ, Sheats JL, Hekler EB, Otten JJ, Grieco LA, et al. The Stanford Healthy Neighborhood Discovery Tool: a computerized tool to assess active living environments. Am J Prev Med. 2013;44(4):e41-7.

21. Sheats JL, Winter SJ, Padilla-Romero P, Goldman RL, Grieco LA, King AC. Comparison of Passive Versus Active Photo Capture of Built Environment Features by Technology Naive Latinos Using the SenseCam and Stanford Healthy Neighborhood Discovery Tool. SenseCam's Proceedings of the 4th International SenseCam \& Pervasive Imaging Conference. 2013;8-15.

22. Sheats JL, Winter SJ, Romero PP, King AC. FEAST: empowering community residents to use technology to assess and advocate for healthy food environments. J Urban Health. 2017;94(2):180-9.

23. King AC, Winter SJ, Sheats JL, et al. Leveraging citizen science and information technology for population physical activity promotion. Transl J Am Coll Sports Med. 2016;1(4): 30- 44 .
24. Rosas LG, Salvo D, Winter SJ, Cortes D, Rivera J, Rodriguez NM, et al. Harnessing technology and citizen science to support neighborhoods that promote active living in Mexico. J Urban Health. 2016;93(6): 953-73.

25. Seguin RA, Morgan EH, Connor LM, et al. Rural food and physical activity assessment using a novel e-tablet-based application: findings and opportunities to catalyze change. Prev Chronic Dis. 2015;12:E102.

26. World Bank: World Bank Gini Index; 2012. http://data. worldbank.org/indicator/SI.POV.GINI/. Accessed July 9, 2017.

27. The Liveability Score. 2017. areavibes.com. Accessed July 1, 2017.

28. Subsecretaría de Prevención del Delito - Ministerio del Interior y Seguridad Pública, BOLETÍN COMUNAL TEMUCO, Victimización ENUSC y casos policiales de delitos de mayor connotación social Año. 2012. 2013. http://www.seguridadpublica.gov.cl/filesapp/09 ENUSC_2012_Temuco.pdf. Accessed July 17, 2017.

29. ArcGIS. My Map. 2017. http://www.arcgis. com/home/webmap/viewer.html?url=http $\% 3 \mathrm{~A} \% 2 \mathrm{~F} \% 2$ Fserviciosgis.catastrobogota.gov.co $\% 2$ Farcgis $\% 2$ Frest $\% 2$ Fservices $\% 2$ Festadisticas $\% 2$ Findicadoresseguridad $\% 2$ FMapServer\&source=sd. Accessed December 26, 2017.

30. Civic Dashboards by OpenGov. Gini Index for San Francisco. http://www.civicdashboards.com/city/sanfrancisco-ca-16000US0667000/gini_index. Accessed December 5, 2017.

31. Alcaldía Mayor de Bogotá. Bogotá Ciudad de Estadísticas. Coeficiente de Gini para Bogotá y la región (2011 y 2014). Bogotá, D.C. 2016 . http://www.sdp.gov. co/portal/page/portal/PortalSDP/InformacionTom aDecisiones/Estadisticas/Bogot\%E1 Ciudad de Estad\%EDsticas/Tab/079 Coeficiente de Gini para Bogot\%E1 y Regi\%F3n. Accessed December 24, 2017.

32. City-Data.com. Bayview district neighborhood in San Francisco, California, 94124 detailed profile. 2017. http://www.city-data.com/neighborhood/Bayview-DistrictSan-Francisco-CA.html. Accessed July 1, 2017.

33. Moran MR, Werner P, Doron I, et al. Exploring the objective and perceived environmental attributes of older adults' neighborhood walking routes: a mixed methods analysis. $J$ Aging Phys Act. 2016:1-36.

34. Winter SJ, Rosas LG, Romero PP, et al. Using citizen scientists to gather, analyze, and disseminate information about neighborhood features that affect active living. J Immigr Minor Health. 2016;18:1126-38.

35. Koohsari MJ, Mavoa S, Villanueva K, Sugiyama T, Badland H, Kaczynski AT, et al. Public open space, physical activity, urban design and public health: concepts, methods and research agenda. Health Place. 2015;33:75-82.

36. Torres A, Diaz MP, Hayat MJ, Lyn R, Pratt M, Sabo D, Sarmiento OL. Assessing the effect of physical activity classes in public spaces on leisure-time physical activity: "Al Ritmo de las Comunidades" A natural experiment in Bogota, Colombia. Prev Med. 2017;(103S):S51-S58.

37. Torres A, Sarmiento OL, Stauber C, Zarama R. Ciclovia and Cicloruta programs: promising interventions to promote physical activity and social capital in Bogotá. Am J Public Health. 2013;103(2):e23-30. 
38. Bennett GG, McNeil LH, Wolin KY, Duncan DT, Puleo E, Emmons KM. Safe to walk? Neighborhood safety and physical activity among public housing residents. PLoS Med. 2007;4(10):e306.

39. Durant N, Kerr J, Harris SK, Saelens BE, Norman GJ, Sallis JF. Environmental and safety barriers to youth physical activity in neighborhood parks and streets: reliability and validity. Pediatr Exerc Sci. 2009;21(1):86-99.

40. Molnar BE, Gortmaker SL, Bull FC, Buka SL. Unsafe to play? Neighborhood disorder and lack of safety predict reduced physical activity among urban children and adolescents. Am J Health Promot. 2004;18(5):378-86.

41. Zieff SG, Guedes CM, Eyler A. Policy-makers' responses to neighborhood focus group outcomes on physical activity. $J$ Phys Act Health. 2012;9(8):1056-64.

42. Kwarteng JL, Schulz AJ, Mentz GB, Israel BA, Shanks TR, Perkins DW. Does perceived safety modify the effectiveness of a walking-group intervention designed to promote physical activity? Am J Health Promot. 2017:890117117696443. https://doi.org/10.1177/0890117117696443. 